\title{
Hubungan Perilaku Lifestyle Without Tobacco dengan Pertumbuhan Anak Usia Dini
}

\author{
Fanny Auliah Hasyim ${ }^{1}{ }^{\bowtie}$, Hadi Pajarianto ${ }^{1}$, Syamsul Alam Ramli ${ }^{1}$ Andi Sitti Umrah ${ }^{2}$, Sri \\ Rahayu Amri2 \\ Pendidikan Guru Pendidikaan Anak Usia Dini, Universitas Muhammadiyah Palopo, \\ Indonesia(1); Kebidanan, Universitas Muhammadiyah Palopo, Indonesia( ${ }^{(2)}$ \\ DOI: $\underline{10.31004 / o b s e s i . v 6 i 4.2362}$
}

\begin{abstract}
Abstrak
Rokok tidak hanya merusak kesehatan manusia, tetapi memberikan dampak terhadap psikologis termasuk pertumbuhan anak usia dini. Penelitian ini bertujuan mengetahui kontribusi Lifestyle Without Tobacco terhadap pertumbuhan anak usia dini. Jenis penelitian ini adalah kuantitatif, partisipan berjumlah 40 orang pada dua desa untuk perbandingan, dan data dianalisis menggunakan uji chi-square. Berdasarkan hasil uji chi-square ditemukan ada hubungan perilaku merokok dengan pertumbuhan anak usia dini, dan dari hasil uji regresi logistik sederhana diperoleh bahwa orang tua yang tidak merokok memiliki peluang 67,7 kali terhadap pertumbuhan anak. Temuan baru penelitian ini merupakan dukungan terhadap penerapan Kawasan Tanpa Rokok (KTR) dengan menerapkan perilaku hidup tanpa tembakau. Anak usia dini yang hidup di lingkungan tersebut memiliki pertumbuhan yang lebih baik. Dampak dari penelitian ini mendorong dapat direplikasi perilaku tanpa asap rokok pada daerah yang memiliki karakteristik yang sama.
\end{abstract}

Kata Kunci: lifestyle without tobacco; pertumbuhan anak; anak usia dini

\begin{abstract}
Cigarettes are not only affected people's health, but from the psychologycal aspect as well including the early childhood grwoth. This study aims to determine the contribution of Lifestyle Without Tobacco towards the $\mathrm{f}$ early childhood growth. This research is a quantitative research, with 40 participants in two villages for comparison, and the data were analyzed using the chi-square test. Based on the result of the chi-square test, it is discovered that there is a relation between smoking habit towards the early childhood growth, and from the result of logistic regression, it is obtained that the parents who are not smoking have 67,7 times chance of child growth. The novelty result of this research is a support to create smokefree areas by applying Lifestyle without Tobacco. Early Childhood who lives in those areas (smoke-free areas) is growing better. The positive impact from this research is to push or support the replication of smoke-free lifestyle in areas which have the same characteristics.
\end{abstract}

Keywods: lifestyle without tobacco; growth; early childhood

Copyright (c) 2022 Fanny Auliah Hasyim, et al.

$\bowtie$ Corresponding author :

Email Address : hadipajarianto@umpalopo.ac.id (Palopo-Sulawesi Selatan)

Received 1 November 2021, Accepted 12 February 2022, Published 25 February 2022 


\section{PENDAHULUAN}

Kebiasaan merokok salah satu problema utama dalam hal kesehatan karena merokok dapat menimbulkan berbagai macam penyakit dan bahkan bisa menjadi penyebab kematian terbesar, terutama di negara miskin dan berkembang (Kusumawardani et al., 2018). Konsumsi rokok akan berdampak pada berkurangnya alokasi dana pemenuhan pangan, pendidikan, dan kesehatan (Ginting \& Maulana, 2020), Bahkan rumah tangga miskin memprioritaskan konsumsi tembakau daripada beras. Konsumsi tembakau merugikan kesehatan dan ekonomi, menempatkan orang dalam lingkaran setan kemiskinan. Fakta ini membuat pemerintah membuat berbagai macam regulasi untuk pengendalian prevalensi perokok, tetapi masih belum maksimal.

Merokok adalah kebiasaan umum dalam masyarakat Indonesia maupun dunia. Bahkan di lingkungan pendidikan, kampus atau sekolah di mana asap tembakau harus bebas. Padahal, asap tembakau mengandung lebih dari 4.000 bahan kimia berbahaya dan lebih dari 43 karsinogen yang dapat membahayakan Anda dan orang-orang di sekitar Anda. Indonesia menempati urutan keenam dalam hal pangsa produsen tembakau terbesar dunia dengan total produksi tembakau 136.000 ton, atau sekitar 1,91\% dari total produksi tembakau dunia. Merokok merupakan hal yg telah terjadi pada negra berkembang pada Indonesia itu sendiri \& masih kurangnya atas warta buat menatasi cara pencegahan \& telah telah terjadi dikalangan manapun (Setiawan et al., 2019). Diperlukan intervensi serius dan dilakukan dengan benar telah mengubah kebiasaan merokok di lingkungan rumah, dan oleh karena itu dibutuhkan keterlibatan masyarakat dan layanan kesehatan masyarakat untuk melacak implementasi intrusi ini dalam jangka panjang (Najmah et al., 2015).

Bagi perokok terdapat banyak alasan untuk merokok secara umum, seperti menghilangkan stres, penampilan maskulin, atau hanya karena ketidaktahuan serta alasan lain untuk berpenampilan menarik (Mayah, 2021). Padahal merokok sangat mempengaruhi perilaku manusia ke arah yang negatif. Penggunaan tembakau dan paparan asap rokok (SHS) juga menjadi penyebab utama dari penyakit yang dapat dicegah, kecacatan, dan kematian di Amerika Serikat dan bertanggung jawab atas sekitar 480.000 kematian setiap tahunnya, enam belas juta lebih orang hidup dengan penyakit serius terkait tembakau (Buettner-Schmidt et al., 2019). Diperlukan suatu kesadaran kolektif agar perilaku Lifestyle Without Tobacco menjadi budaya dan kultur masyarakat sehingga kualitas hidup dapat ditingkatkan serta menjadi upaya pemerintah dan masyarakat untuk melakukan diseminasi kawasan tanpa rokok (Khairatunnisa \& Fachrizal, 2019).

Beberapa penelitian sebelumnya yang menemukan korelasi antara perilaku merokok orang dewasa terhadap pertumbuhan anak usia dini, utamanya stunting (Sari \& Resiyanthi, 2020). Kebaruan dari penelitian ini dilaksanakan pada dua lokasi yang menerapkan Kawasan Tanpa Asap Rokok (KTR) dengan prevalensi 0 (nol) persen, dan pada kawasan yang belum menerapkan Kawasan tanpa Asap Rokok dengan prevalensi 81 (delapan puluh satu) persen. Dengan adanya sampel kontrol tersebut diharapkan dapat memberikan data yang lebih akurat adanya perbedaan pertumbuhan anak usia dini pada daerah yang menerapkan dan tidak menerapkan KTR.

Pertumbuhan merupakan perubahan biologis, anatomis, dan fisiologis individu (Hidayati, 2017). Pertumbuhan fisik pada anak menyebabkan peningkatan ukuran tubuh. Puncak pertumbuhan fisik anak usia 3 tahun ke atas adalah usia 6-12 tahun di sekolah (Damayanti et al., 2017). Proses pertumbuhan tinggi badan (TB) relatif cepat dan disertai dengan peningkatan berat badan (BB). Perubahan pertumbuhan fisik terlihat pada saat pertumbuhan fisik usia sekolah memasuki usia sekolah yang mencerminkan status gizi bayi. Selain itu, lingkungan yang tidak sehat juga turut memberikan andil terhadap pertumbuhan anak usia dini, termasuk kejadian stunting (Sari \& Resiyanthi, 2020). Tugas utama keluarga sebagai lingkungan utama anak adalah mempertahankan suasana di rumah yang menguntungkan kesehatan dan perkembangan kepribadian anggota keluarga, dengan tidak 
merokok. Perilaku merokok secara teoretik dan faktual akan menyebabkan terganggunya pertumbuhan dan perkembangan anak.

Pada usia 0-6 tahun, atau yang biasa disebut dengan masa keemasan, proses pertumbuhan dan perkembangan berada pada puncaknya. Masa keemasan merupakan masa kritis yang dimulai antara usia 0 hingga 5 tahun dan terjadi sekali dalam kehidupan seorang anak (Herlina, 2018). Pada usia muda, anak biasanya tumbuh dan berkembang sangat cepat dan tidak terulang kembali di kemudian hari. Sangat mudah untuk meniru dan menyerap apa yang dilihat dan diterima di lingkungan selama masa bayi. Pendidikan Anak Usia Dini adalah keliru satu bentuk pendidikan prasekolah. Pendidikan prasekolah merupakan pendidikan buat membantu pertumbuhan \& perkembangan jasmani \& rohani anak diluar lingkungan famili sebelum memasuki pendidikan dasar (Kurnia et al., 2020).

Taman kanak-kanak adalah salah satu bentuk pendidikan anak usia dini yang terdapat pada jalur pendidikan formal sekolah (Nurdin \& Anhusadar, 2020). Lingkungan yang baik mendorong anak-anak menjadi baik, dan lingkungan yang buruk mempengaruhi anak-anak berbuat buruk. Menurut Piaget (Prasanti \& Fitrianti, 2018), usia anak usia dini berkisar dari tahap sensorimotor (0-2 tahun) hingga pra operasional (2-6 tahun). Secara pedagogis, usia dini sangat menetukan kehidupan anak di masa yang akan datang, apakah kehidupannya akan baik, bahagia atau sebaliknya. Pada masa inilah pendidikan baik dalam rumah tangga, sekolah, dan masyarakat menjadi sangat krusial dan menentukan (Rahmatia et al., 2021). Pertumbuhan dan perkembangan intelektual seorang anak dapat dilihat melalui kemampuan simbolik dan abstrak seperti berbicara, bermain, berhitung, dan perkembangan emosional anak dapat dilihat melalui perilaku sosial di lingkungan anak (Zualichoh \& Irdawati, 2020).

Masa usia dini adalah satu masa yang krusial pada kehidupan manusia. Hal ini lantaran dalam masa usia dini anak mulai peka atau sensitif buat mendapat aneka macam macam rangsangan berdasarkan luar diri anak. (Wulandari \& Purwanta, 2020). Pertumbuhan dan perkembangan anak merupakan penyingkapan sedikit demi sedikit yang dipengaruhi secara biologis ciri \& sifat yang ada waktu anak belajar berdasarkan pengalaman. Di negara berkembang, lebih berdasarkan 200 juta anak balita tahun gagal mencapai potensi mereka pada perkembangan kognitif \& sosial lantaran kemiskinan, kesehatan yang buruk, gizi, \& defisit perawatan. Anak-anak tinggal pada Asia Selatan \& Afrika Sub-Sahara \& poly pada antaranya dihadapkan dalam aneka macam risiko termasuk kemiskinan, kekurangan gizi, kesehatan \& lingkungan tempat tinggal yang tidak merangsang, yang merugikan menghipnotis perkembangan \& pertumbuhan mereka (Deki Pem, 2016). Konsep tumbuh kembang anak ditampilkan pada gambar 1.

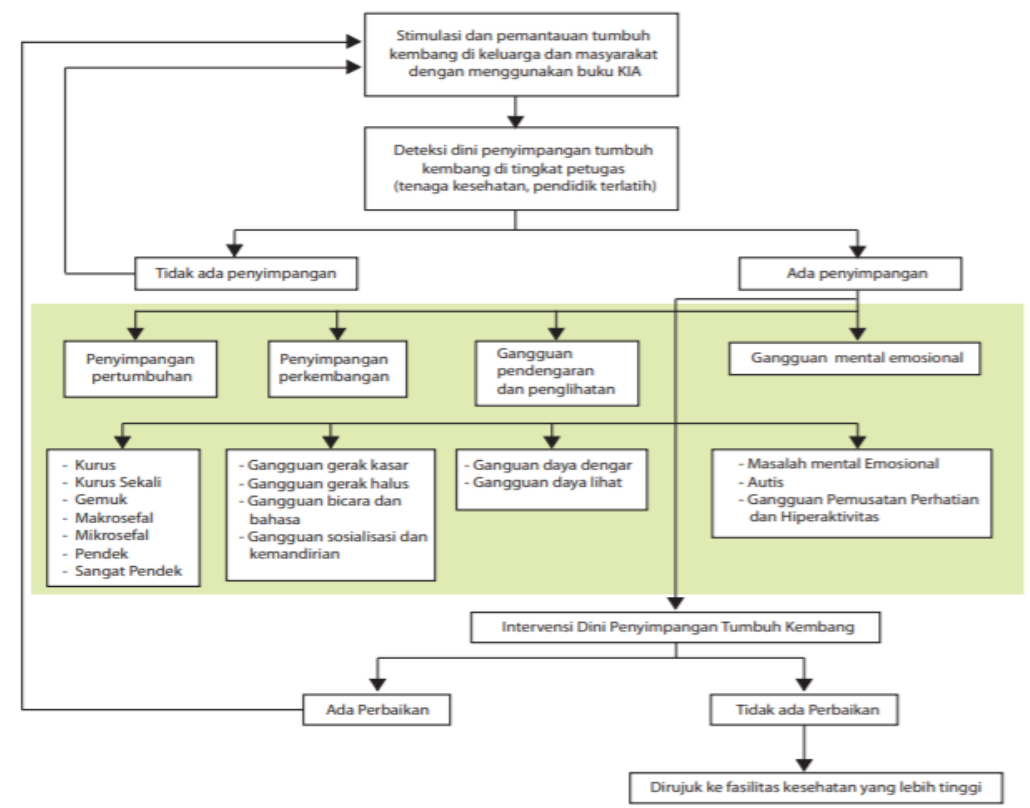

Gambar 1. Kerangka Konsep Tumbuh kembang Anak (Kemenkes, 2016) 
Secara umum, berat badan, tinggi badan, dan lingkar kepala anak diukur dan dipantau. Anak-anak tumbuh dan berkembang, dan mereka dicirikan oleh pertumbuhan dan perkembangan yang konstan dari konsepsi hingga akhir masa remaja. Inilah yang membedakan anak-anak dengan orang dewasa (Kemenkes, 2016). Anak-anak bukanlah orang dewasa kecil. Anak memiliki karakteristik tumbuh kembang yang sesuai dengan usianya. Perbedaan antara pertumbuhan dan perkembangan adalah bahwa pertumbuhan dapat diukur dalam satuan karena pertumbuhan mengacu pada peningkatan ukuran dan jumlah sel dan jaringan antar sel, yang mengakibatkan peningkatan sebagian atau seluruhnya pada beberapa atau sebagian struktur tubuh.

Di kecamatan Baraka kabupaten Enrekang Provinsi Sulawesi Selatan terdapat satu desa bernama Bone-Bone. Desa Bone-Bone merupakan salah satu desa percontohan yang menetapkan desa bebas tanpa rokok di Indonesia. Pengakuan dari organisasi kesehatan dunia atau WHO ini di dukung sebagai desa dengan gaya hidup sehat (Lifestyle Without Tobacco) pada tahun 2012 (Hadilinatih, 2021). Gaya hidup sehat memberikan dampak baik bagi kesehatan masyarakat, dan juga menurunnya jumlah warga yang mengidap penyakit ispa. Oleh karena itu, masyarakat menetapkan perdes ini, prevalensi perokok di desa tersebut 0 (nol) persen (Filial \& Rais, 2021). Dari sisi ekonomi, kehidupan masyarakat desa Bone-Bone dapat dikatakan baik dan meningkat berbeda dengan pada saat sebelum adanya kebijakan larangan merokok yang masih banyak pembungkus dan puntung rokok berserakan dimanamana baik dilingkungan maupun di ruang-ruang umum.

Penelitian ini memiliki kontribusi penting karena dilakukan pada kawasan yang telah menerapkan Lifestyle Without Tobacco dan telah menjadi kultur masyarakat baik secara budaya maupun pengamalan agama. Selain itu, juga menerapkan responden pada kawasan lain yang angka perokoknya masih tinggi sehingga dapat dilakukan perbandingan data. Penelitian ini bertujuan untuk: (i) mengidentifikasi pola hidup Lifestyle Without Tobacco pada keluarga yang memiliki anak usia dini; (ii) mengidentifikasi pertumbuhan fisik pada anak usia dini; dan (iii) mengetahui kontribusi Lifestyle Without Tobacco terhadap pertumbuhan anak usia dini.

\section{METODOLOGI}

Penelitian ini dilakukan di desa Bone-Bone kecamatan Baraka kabupaten Enrekang, sebagai daerah di kaki gunung Latimojong dengan tingkat prevalensi perokok nol persen. Desa ini telah memiliki Peraturan Desa nomor 1 Tahun 2009 tentang Kawasan Bebas Asap Rokok. Salah satu inovasi yang diusung oleh pemerintah Desa Bone untuk pendidikan dan pembangunan desa untuk kesejahteraan masyarakat adalah pembentukan desa bebas rokok untuk menciptakan lingkungan yang sehat. Pemerintah setempat telah menetapkan aturan untuk mencegah masyarakat desa dan siapa pun yang berkunjung ke desa untuk merokok, menjual, atau sekadar memasang iklan rokok di poster atau bentuk lain di kawasan Desa Bone Bone.

Jenis penelitian ini adalah kuantitatif yang menggunakan desain korelasi. Studi korelasi bertujuan untuk mengidentifikasi hubungan antar variabel (Nursalam, 2016 \& Fallis, 2013). Pendekatan yang digunakan adalah cross-sectional, untuk mempelajari dinamika korelasi antara faktor-faktor risiko dengan efek, dengan cara pendekatan, observasional, atau pengumpulan data. Penelitian cross-sectional hanya mengobservasi sekali saja dan pengukuran dilakukan terhadap variabel subjek pada saat penelitian. Sampel dalam penelitian ini berjumlah 40 orang, masing-masing 20 orang di Desa Bone-bone dan Kontrol (Salukanan) di kabupaten Enrekang. Kriteria inklusi dalam penelitian ini adalah orang tua balita yang memiliki anak usia 3-5 tahun dan bersedia menjadi responden.

Teknik pengambilan sampel secara purposive pada desa Bone-Bone dan Salukanan. Penelitian ini menggunakan alat bantu berupa Kuesioner Merokok dan Kuesioner Tumbuh Kembang yang dikeluarkan oleh Kementerian Kesehatan. Kuisioner ini berisi tentang identitas responden, perilaku merokok, dan informasi berat dan tinggi badan anak usia dini. Kisi-kisi instrumen disajikan pada tabel 1. 
Tabel 1. Kisi-Kisi Instrumen Penelitian

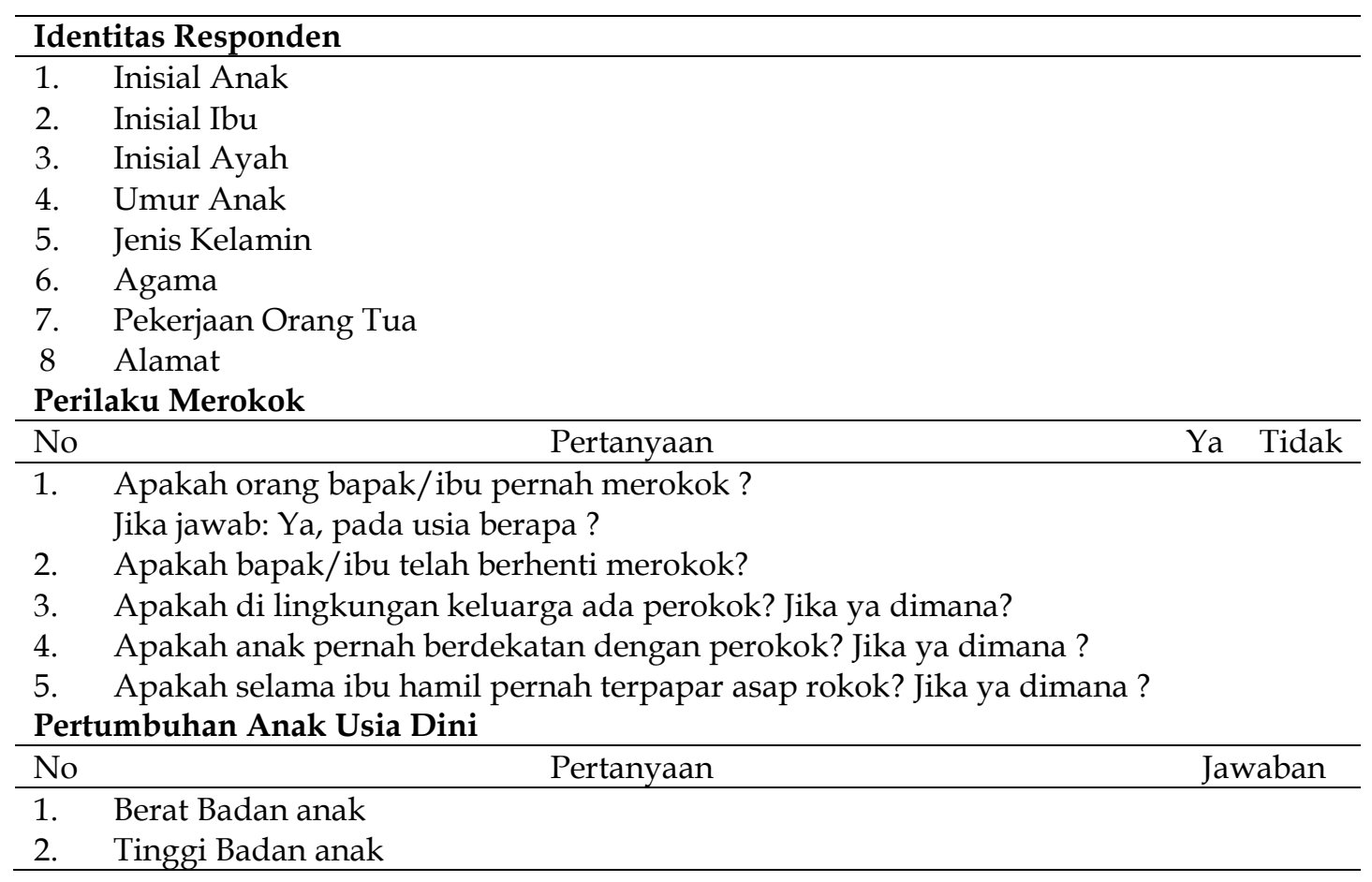

Data yang dikumpulkan melalui kuisioner pada tabel 1. kemudian ditabulasi dan dianalisis. Jika data yang diperoleh dari hasil pengumpulan dianalisis secara satu dimensi, maka dapat disajikan dalam bentuk distribusi frekuensi. Analisis dua dimensi dilakukan pada dua variabel yang dinilai berhubungan atau berkorelasi, dan peneliti menggunakan uji chi square dan uji regresi logistik sederhana. Berikut ini digambarkan siklus dan tahapan penelitian secara lengkap dan utuh. Prosedur dan tahapan penelitian ditampilkan pada gambar 2 .

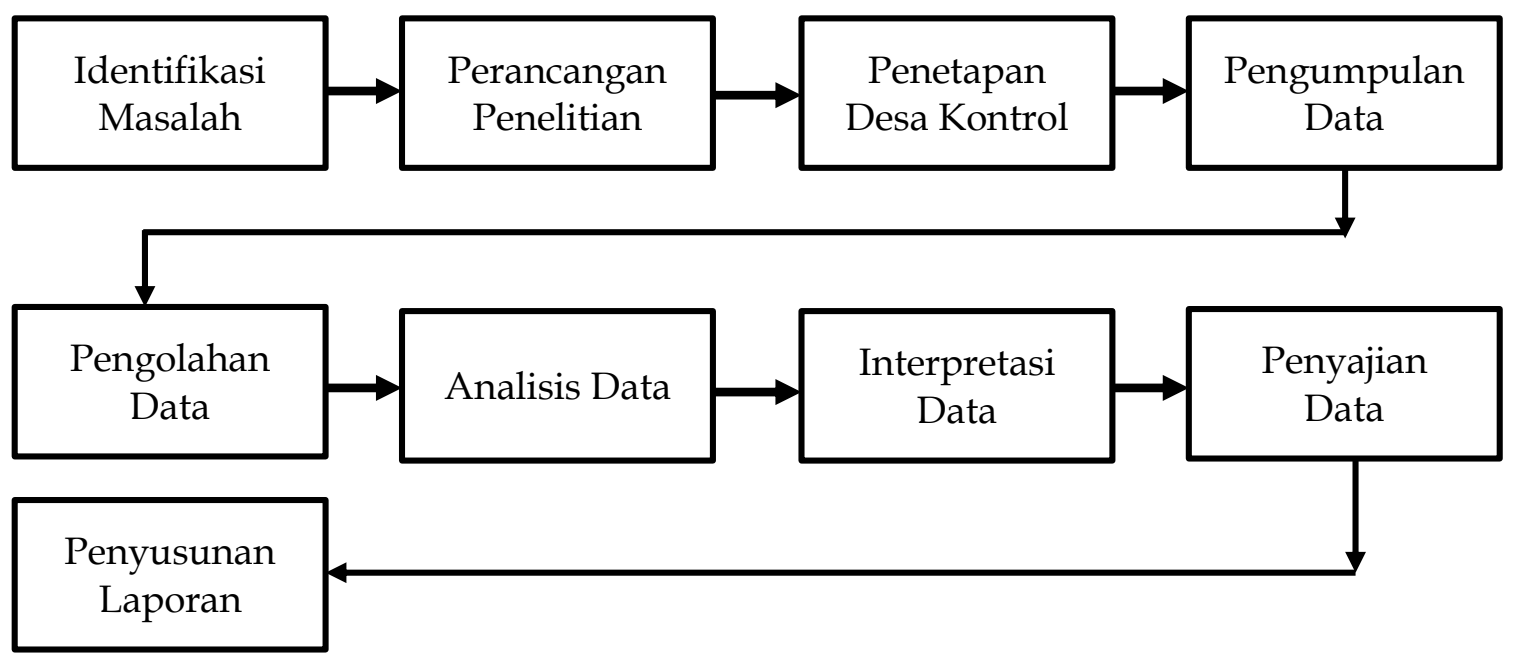

Gambar 2. Prosedur dan Tahapan Penelitian

\section{HASIL DAN PEMBAHASAN}

Pola Hidup Lifestyle Without Tobacco

Pola hidup pada masyarakat desa sangat dipengaruhi oleh faktor sosiologis, budaya, dan pemahaman keagamaan. Perilaku hidup tanpa asap rokok terkait dengan pemahaman agama bahwa rokok dapat merusak tubuh dan bertentangan dengan ajaran agama Islam 
sebagai agama mayoritas di Desa Bone-Bone. Mereka dapat berfikir positif untuk diri sendiri maupun orang lain, untuk keluarga, keturunan, jiwa, pikiran dan kesucian diri serta agama (wawancara., MI). Beberapa intervensi serius dan dilakukan dengan benar telah mengubah kebiasaan merokok di lingkungan rumah, dan oleh karena itu dibutuhkan keterlibatan masyarakat dan layanan kesehatan masyarakat sekitar tahun untuk melacak implementasi intrusi ini dalam jangka panjang (Najmah et al., 2015). Karakteristik responden disajikan pada tabel 2.

Tabel 2. Distribusi frekuensi berdasarkan karakteristik responden

\begin{tabular}{lcc}
\hline Karakteristik Responden & $\begin{array}{c}\text { Frekuensi } \\
(\mathbf{F})\end{array}$ & $\begin{array}{c}\text { Persentase } \\
(\mathbf{\%})\end{array}$ \\
\hline Jenis kelamin & & \\
Laki-laki & 14 & 35,0 \\
Perempuan & 26 & 65,0 \\
Total & 40 & 100,0 \\
\hline Usia & & \\
3 tahun & 5 & 12,5 \\
4 tahun & 20 & 50,0 \\
5 tahun & 15 & 37,5 \\
Total & 40 & 100,0 \\
\hline Domisili (Alamat) & & \\
Desa Bone-bone (KTR) & 20 & 50,0 \\
Desa Salukanan (Non KTR) & 20 & 50,0 \\
Total & 40 & 100,0 \\
\hline \multicolumn{2}{c}{ Sumber: data primer }
\end{tabular}

Berdasarkan tabel 2. tentang distribusi frekuensi karakteristik responden menurut jenis kelamin menyatakan bahwa anak dengan jenis kelamin laki-laki sebanyak 14 orang (35\%) dan perempuan sebanyak 26 orang $(65 \%)$. Sedangakan menurut usia, diperoleh data anak usia 3 tahun sebanyak 5 orang $(12,5 \%)$, anak usia 4 tahun sebanyak 20 orang (50\%) dan anak usia 5 tahun sebanyak 15 orang (37,5\%). Menurut domisili (alamat tempat tinggal), desa bone-bone sebagai desa yang mengimplementasikan KTR sebanyak 20 orang (50\%) dan desa salukanan sebagai desa pembanding/kontrol (non KTR) sebanyak 20 orang (50\%). Perilaku merokok pada responden di dua desa ditampilkan pada tabel 3.

Tabel 3. Distribusi frekuensi berdasarkan perilaku merokok

\begin{tabular}{lcc}
\hline Perilaku merokok & $\begin{array}{c}\text { Frekuensi } \\
\text { (F) }\end{array}$ & $\begin{array}{c}\text { Persentase } \\
(\mathbf{\%})\end{array}$ \\
\hline Ya & 10 & 25,0 \\
Tidak & 30 & 75,0 \\
Total & 40 & 100,0 \\
\hline \multicolumn{3}{c}{ Sumber: data primer }
\end{tabular}

Berdasarkan tabel 3. tentang perilaku merokok menyatakan bahwa dari 40 jumlah responden, sebanyak 30 orang $(75 \%)$ yang tidak merokok dan sebanyak 10 orang $(25 \%)$ yang merokok. Data ini menunjukkan bahwa mayoritas orang tua responden dari dua desa tidak merokok, yang dari analisis sederhana didorong oleh implementasi peraturan desa yang menerapkan kawasan tanpa asap rokok. Desa Bone-Bone terlah berhasil menerapkan Perdes kasawan tanpa rokok, sedangkan desa Salukanan pernah melakukan inisiasi pembentukan Perdes serupa tetapi tidak berhasil karena besarnya penolakan dari tokoh masyarakat dan tokoh pemuda yang belum siap melaksanakan Perdes tersebut. Namun demikian, desa 
Salukanan memiliki rencana untuk kembali membuat Perdes tersebut. Perbandingan perilaku merokok pada desa Bone-Bone dan Salukanan disajikan pada tabel 4.

Tabel 4. Distribusi Frekuensi Perilaku Merokok

\begin{tabular}{lcc}
\hline \multicolumn{1}{c}{ Perilaku merokok } & $\begin{array}{c}\text { Frekuensi } \\
\text { (F) }\end{array}$ & $\begin{array}{c}\text { Persentase } \\
(\mathbf{\%})\end{array}$ \\
\hline Desa Bone-bone (Kawasan Tanpa Rokok) & 0 & 0,0 \\
Ya & 20 & 100,0 \\
Tidak & 20 & 100,0 \\
Total & & \\
\hline Desa Salu kanan (Belum Menerapkan Kawasan Tanpa Rokok) & 10 & 50,0 \\
Ya & 10 & 50,0 \\
Tidak & 20 & 100,0 \\
Total & & \\
\hline
\end{tabular}

Sumber: data primer

Berdasarkan tabel 4. tentang perilaku merokok berdasarkan domisili menyatakan bahwa dari 20 jumlah responden pada masing-masing daerah, sebanyak 20 orang (100\%) yang tidak merokok pada desa bone-bone. Sedangkan pada desa salukanan sebanyak 10 orang (50\%) yang tidak merokok dan sebanyak sebanyak 10 orang $(50 \%)$ yang merokok. Perilaku tanpa asap rokok di desa Bone-Bone juga terkait dengan kesehatan. Masyarakat juga meyakini bahwa rokok dapat menyebabkan bertambahnya pengeluaran keluarga yang seharusnya dapat dimanfaatkan untuk Pendidikan anak-anaknya (wawancara, MI) dan juga kualitas udara yang bersih, rendahnya polusi udara, kondisi alam yang masih asli, masalah perlindungan kesehatan, serta terciptanya lingkungan yang sehat untuk masyarakat Desa Bone-bone dan dapat dikembangkan lebih lanjut sebagai salah satu kawasan wisata.

\section{Pertumbuhan Fisik Pada Anak Usia Dini}

Anak usia dini merupakan individu yang sedang mengalami proses tumbuh kembang yang fundamental bagi kehidupannya kelak. Pada tahapan usia dini, anak akan mengalami perkembangan dan pertumbuhan fisik serta mental yang cukup banyak. Gizi seimbang harus diterapkan sejak anak usia dini karena kelompok ini termasuk kelompok usia penting dan kelompok kritis tumbuh kembang manusia yang akan menentukan masa depan kualitas hidup manusia (Inten \& Permatasari, 2019). Pertumbuhan adalah meningkatnya jumlah dan ukuran sel pada saat membelah diri dan mensintesis protein baru yang menghasilkan peningkatan ukuran berat seluruh atau sebagian sel (Septiani et al., 2016). Asupan makanan pada anak usia dini harus lebih diperhatikan zat zat gizinya terutama protein yang membantu proses pertumbuhan berat badan, selain penyediaan untuk asupan pertumbuhan otak dan kecerdasan (Primasoni, 2019). Kebutuhan gizi sejak usia dini sangat penting, asupan gizi yang seimbang akan membuat anak tumbuh sehat dan cerdas begitupun dengan pertumbuhan fisiknya, demikian juga sebaliknya. Distribusi pertumbuhan anak usia dini berdasarkan berat badan/umur disajikan pada tabel 5 .

Berdasarkan tabel 5. tentang pertumbuhan anak berdasarkan BB/U menunjukkan bahwa dari 20 responden pada masing-masing desa, diperoleh data pada desa bone-bone pertumbuhan anak dengan berat badan normal sebanyak 19 orang (95\%) dan berat badan kurang sebanyak 1 orang (5\%). Sedangkan pada desa salukanan, pertumbuhan anak dengan berat badan normal sebanyak 13 orang (65\%) dan berat badan kurang sebanyak 7 orang (35\%). Distribusi pertumbuhan berdasarkan panjang badan/umur disajikan pada tabel 6.

Berdasarkan tabel 6. tentang pertumbuhan anak berdasarkan TB/U menunjukkan bahwa dari 20 responden pada masing-masing desa, diperoleh data pada desa bone-bone pertumbuhan anak dengan tinggi badan normal sebanyak 20 orang $(100 \%)$. Sedangkan pada 
desa salukanan, pertumbuhan anak dengan tinggi badan normal sebanyak 15 orang $(75 \%)$ dan yang mengalami tinggi badan pendek (stunted) sebanyak 5 orang $(25 \%)$.

Tabel 5. Distribusi pertumbuhan anak berdasarkan Berat Badan/Umur

\begin{tabular}{lcc}
\hline \multicolumn{1}{c}{$\begin{array}{c}\text { Pertumbuhan anak menurut } \\
\text { Berat Badan/Umur }\end{array}$} & $\begin{array}{c}\text { Frekuensi } \\
(\mathbf{F})\end{array}$ & $\begin{array}{c}\text { Persentase } \\
\mathbf{( \% )}\end{array}$ \\
\hline Desa Bone-Bone (Kawasan Tanpa Rokok) & & \\
Normal & 19 & 95,0 \\
Kurang (Underweight) & 1 & 5,0 \\
Total & $\mathbf{2 0}$ & $\mathbf{1 0 0 , 0}$ \\
\hline Desa Salukanan (Belum Menerapkan Kawasan Tanpa Rokok) & & \\
Normal & 13 & 65,0 \\
Underweight & 7 & 35,0 \\
Total & $\mathbf{2 0}$ & $\mathbf{1 0 0 , 0}$ \\
\hline
\end{tabular}

Sumber: data primer

Tabel 6. Distribusi pertumbuhan anak berdasarkan Panjang Badan/Umur

\begin{tabular}{lcc}
\hline \multicolumn{1}{c}{$\begin{array}{c}\text { Pertumbuhan anak menurut } \\
\text { Panjang/Umur }\end{array}$} & $\begin{array}{c}\text { Frekuensi } \\
(\mathbf{F})\end{array}$ & $\begin{array}{c}\text { Persentase } \\
(\%)\end{array}$ \\
\hline Desa Bone-Bone (Kawasan Tanpa Rokok) & 20 & 100 \\
Normal & 0 & 0,0 \\
Pendek/stunted & 20 & 100,0 \\
Total & 15 & 75,0 \\
\hline Desa Salukanan (Belum Menerapkan Kawasan Tanpa Rokok) & 5 & 25,0 \\
Normal & 20 & 100,0 \\
Pendek/stunted & & \\
Total
\end{tabular}

Sumber: data primer

Tabel 7. Distribusi pertumbuhan anak berdasarkan BB/U dan PB/Umur

\begin{tabular}{lcc}
\hline Pertumbuhan anak & $\begin{array}{c}\text { Frekuensi } \\
\text { (F) }\end{array}$ & $\begin{array}{c}\text { Persentase } \\
\text { (\%) }\end{array}$ \\
\hline BB/Umur & & \\
Normal & 32 & 80,0 \\
Kurang (Underweight) & 8 & 20,0 \\
Total & 40 & 100,0 \\
\hline Tinggi badan/umur & & \\
Normal & 35 & 87,5 \\
Pendek/stunted & 5 & 12,5 \\
Total & 40 & 100,0 \\
\hline \multicolumn{2}{c}{ Sumber: data primer }
\end{tabular}

Berdasarkan tabel 7. tentang pertumbuhan anak berdasarkan BB/U dan TB/U menunjukkan bahwa dari 40 orang jumlah responden secara keseluruhan, diperoleh data $\mathrm{BB} / \mathrm{U}$ pertumbuhan anak dengan berat badan normal sebanyak 32 orang $(80 \%)$ dan berat badan kurang (underweight) sebanyak 8 orang (20\%). Sedangkan berdasarkan TB/U pertumbuhan anak dengan tinggi badan normal sebanyak 35 (87,5\%) dan anak pendek/stunted sebanyak 5 orang $(12,5 \%)$.

Masa kanak-kanak dari usia 0-6 tahun disebut masa emas (golden age) yang terjadi hanya dalam sekali perkembangan kehidupan manusia sehingga sangatlah penting merangsang pertumbuhan anak usia dini dengan memberikan perhatian terhadap kesehatan 
anak, penyediaan gizi yang cukup dan pelayanan pendidikan (Aris Priyanto, 2014) . Pertumbuhan dan perkembangan dapat dilakukan dengan melalui tiga pilar pelayanan, yaitu layanan kesehatan, asupan gizi, dan stimulasi psikososial (Hadi Siswanto, 2019). Pemberian layanan yang tepat dan berkualitas dapat dilakukan dengan baik apabila orang tua, utamanya ibu pengasuh dan pendidik anak usia dini memiliki pengetahuan dan pemahaman tentang layanan kesehatan, gizi dan stimulasi psikososial sesuai dengan kebutuhan pertumbuhan dan perkembangan anak usia dini.

\section{Kontribusi Perilaku Lifestyle Without Tobacco}

Perilaku merokok dalam beberapa teori dapat memberikan dampak buruk yang dihasilkan dari rokok salah satunya dapat menyebabkan berbagai penyakit yang sangat membahayakan kesehatan khususnya pertumbuhan anak usia dini. Melihat besarnya resiko perilaku merokok, pemerintah indonesia berupaya untuk menekan semakin tingginya angka prevalensi merokok pada usia muda (Tantri et al., 2018). Mengingat anak usia dini membutuhkan lingkungan yang sehat dan layak bagi pertumbuhannya. Kontribusi Lifestyle Without Tobacco terhadap pertumbuhan anak usia dini disajikan pada tabel 8 .

Tabel 8. Kontribusi Lifestyle Without Tobacco Terhadap Pertumbuhan Anak Usia Dini

\begin{tabular}{|c|c|c|c|c|c|c|c|}
\hline \multirow{3}{*}{ Perilaku merokok } & \multicolumn{4}{|c|}{ Pertumbuhan Anak Berdasarkan Berat Badan/Umur } & \multirow{2}{*}{\multicolumn{2}{|c|}{ Total }} & \multirow[t]{3}{*}{$\rho$} \\
\hline & \multicolumn{2}{|c|}{ Normal } & \multicolumn{2}{|c|}{ Underweight } & & & \\
\hline & n & $\%$ & $\mathbf{n}$ & $\%$ & $\mathbf{N}$ & $\%$ & \\
\hline $\mathrm{Ya}$ & 3 & 7,5 & 7 & 17,5 & 10 & 25,0 & \\
\hline Tidak & 29 & 72,5 & 1 & 2,5 & 30 & 75,0 & $0,000^{*}$ \\
\hline Total & 32 & 80,0 & 8 & 20,0 & 40 & 100 & \\
\hline \multirow{3}{*}{ Perilaku merokok } & \multicolumn{4}{|c|}{ Pertumbuhan Anak Berdasarkan Tinggi Badan/Umur } & \multirow{2}{*}{\multicolumn{2}{|c|}{ Total }} & \multirow[t]{3}{*}{$\rho$} \\
\hline & \multicolumn{2}{|c|}{ Normal } & \multicolumn{2}{|c|}{ Pendek/Stunted } & & & \\
\hline & $\mathbf{n}$ & $\%$ & $\mathbf{n}$ & $\%$ & $\mathbf{N}$ & $\%$ & \\
\hline $\mathrm{Ya}$ & 5 & 12,5 & 5 & 12,5 & 10 & 100 & \\
\hline Tidak & 30 & 75,0 & 0 & 5,0 & 30 & 100 & $0,000^{*}$ \\
\hline Total & 35 & 87,5 & 5 & 17,5 & 40 & 100 & \\
\hline
\end{tabular}

*Uji chi-square

Berdasarkan tabel 8. menunjukkan bahwa dari 40 jumlah responden, diperoleh data pada pertumbuhan anak menurut $\mathrm{BB} / \mathrm{U}$ terdapat sebanyak 5 orang $(12,5 \%)$ yang memiliki orang tua perokok dengan berat badan normal, dan sebanyak 7 orang $(17,5 \%)$ yang memiliki orang tua perokok dengan berat badan kurang. Sedangkan sebanyak 29 orang $(72,5 \%)$ yang memiliki orang tua tidak merokok dengan berat badan normal, dan tidak ada yang memiliki orang tua tidak merokok dengan berat badan kurang. Selanjutnya berdasarkan TB/U diperoleh data bahwa sebanyak 5 orang $(12,5 \%)$ yang memiliki orang tua perokok dengan tinggi badan normal, dan sebanyak 5 orang $(12,5 \%)$ yang memiliki orang tua perokok dengan tinggi badan pendek/stunted. Sedangkan sebanyak 30 orang (72,5\%) yang memiliki orang tua tidak merokok dengan tinggi badan normal, dan tidak ada yang memiliki orang tua tidak merokok dengan tinggi badan pendek/stunted.

Berdasarkan hasil uji chi-square diperoleh nilai $\rho=0,000<$ nilai $\alpha=0,05$. Hal ini berarti ada ada hubungan perilaku merokok dengan pertumbuhan anak usia dini dilihat dari berat badan/umur dan tinggi badan/umur. Dari analisis data dapat disimpulkan bahwa perilaku Lifestyle Without Tobacco memberikan kontribusi terhadap pertumbuhan anak usia dini. Analisis multivariat perilaku merokok terhadap pertumbuhan anak disajikan pada tabel 9.

Berdasarkan hasil uji regresi logistik sederhana diperoleh bahwa nilai $\rho=0,001<$ nilai $a=0,05$, nilai $\operatorname{Exp}(B)=67,7$. Hal ini berarti bahwa ada hubungan perilaku merokok terhadap pertumbuhan anak berdasarkan $\mathrm{BB} / \mathrm{U}$ dan $\mathrm{TB} / \mathrm{U}$. Interpretasi adalah orang tua yang tidak 
merokok memiliki peluang 67,7 kali terhadap pertumbuhan anak dengan berat badan yang normal.

Tabel 9. Analisis multivariat perilaku merokok terhadap pertumbuhan anak

\begin{tabular}{|c|c|c|c|c|c|c|c|c|c|}
\hline \multicolumn{10}{|c|}{ Variables in the Equation } \\
\hline & & \multirow[b]{2}{*}{ B } & \multirow[b]{2}{*}{ S.E. } & \multirow[b]{2}{*}{ Wald } & \multirow[b]{2}{*}{$\mathrm{df}$} & \multirow[b]{2}{*}{ Sig. } & \multirow[b]{2}{*}{$\operatorname{Exp}(B)$} & $\begin{array}{r}95 \% \mathrm{C} \\
\mathrm{EXI} \\
\end{array}$ & $\begin{array}{l}\text { C.I.for } \\
\text { (B) }\end{array}$ \\
\hline & & & & & & & & Lower & Upper \\
\hline \multirow[t]{2}{*}{ Step 1a } & $\begin{array}{l}\text { Perilaku } \\
\text { merokok(1) }\end{array}$ & 4,215 & 1,229 & 11,758 & 1 & 001 & 67,667 & 6,084 & 752,631 \\
\hline & $\overline{\text { Constant }}$ & $-3,367$ & 1,017 & 10,961 & 1 & ,001 & 034 & & \\
\hline
\end{tabular}

a. Variable(s) entered on step 1: Perilaku merokok.

**uji regresi logistik sederhana

Penelitian ini membuktikan bahwa perilaku tanpa asap rokok selain terkait dengan kesehatan pola hidup tanpa asap rokok juga terikat masalah ekonomi masyarakat Desa Bonebone yaitu berfikir bahwa orang yang merokok akan mengeluarkan banyak uang untuk membeli rokok sehingga biaya untuk keperluan pendidikan akan kurang dan akhirnya tidak mampu membiayai sekolah mereka (Pewara, 2018). Di sisi lain rokok dapat menyebabkan dampak buruk terhadap masyarakat karena produktivitas yang hilang, dan beban keuangan yang ditanggung oleh perokok juga besar dan disini sangat jelas bahwa merokok sangat membahayakan kesehatan dan merugikan perekonomian masyarakat (Buettner-Schmidt et al., 2019).

Secara implementatif perlu didorong lahirnya peraturan pada berbagai level untuk menerapkan Kawasan Tanpa Rokok. Terbukti Peraturan Desa Bone-Bone tentang Kawasan Tanpa Rokok memberikan dampak yang baik bagi kesehatan masyarakat, peningkatan kesehatan masyarakat dengan menurunnya jumlah warga yang mengidap penyakit ISPA (Muhammad Amin Rais, 2021). Saat ini, kawasan tanpa rokok dan pelarangan iklan, promosi, dan sponsor rokok menjadi salah satu indikator dari kota layak anak. Kehadiran Kotak Layak Anak yang selanjutnya disebut KLA yang dapat diderivasi menjadi desa layak anak merupakan bentuk pengejawantahan atas Konvensi PBB mengenai Hak Anak pada tahun 1989, World Fit For Children (Pasca et al., 2018). Melalui undang-undang No 20 Tahun 2003 tentang Perlindungan anak maka inisiasi Kota/Kabupaten Kota Layak Anak menjadi salah satu program yang difungsikan guna mengembangkan kondisi wilayah Kota/Kabupaten agar dapat memenuhi kebutuhan anak. Salah satunya pada aspek pemenuhan kesehatan dan kesejahteraan pada anak.

\section{SIMPULAN}

Hasil analisis data ditemukan adanya perbedaan pertumbuhan anak usia dini pada kawasan yang menerapkan kawasan tanpa asap rokok dan desa yang tidak menerapkan kawasan tanpa asap rokok. Kesimpulan dari penelitian ini adalah ditemukan adanya hubungan antara perilaku kawasan bebas tanpa asap rokok dengan pertumbuhan anak usia dini. Desa Bone-bone dapat direkomendasikan kepada pemerintah pusat dan daerah sebagai desa percontohan kawasan bebas tanpa asap rokok, dan layak bagi anak usia dini.

\section{UCAPAN TERIMA KASIH}

Puji dan syukur peneliti panjatkan kepada Allah swt atas segala rahmat dan karuniaNya yang telah memberikan kesehatan dan kesempatan pada peneliti sehingga riset ini dapat diselesaikan dengan baik. Kepada Lembaga Pengelola Dana Pendidikan (LPDP) yang telah memfasilitasi tim peneliti dalam program Riset Keilmuan 2021, dan mahasiswa menjadi 
peserta dalam program tersebut sebagai bagian dari implementasi Merdeka Belajar Kampus Merdeka. Atas segala kekurangan baik secara teknis maupun subtansi dalam penelitian ini akan disempurnakan di masa yang akan datang.

\section{DAFTAR PUSTAKA}

Aris Priyanto. (2014). Pengembangan Kreativitas Pada Anak Usia Dini Melalui Aktivitas Bermain. Jurnal Ilmiah Guru Caraka Olah Pikir Edukatif, 0(2).

Buettner-Schmidt, K., Miller, D. R., \& Maack, B. (2019). Disparities in rural tobacco use, smokefree policies, and tobacco taxes. Western Journal of Nursing Research, 41(8), 1184-1202. https:// doi.org/10.1177/0193945919828061

Damayanti, I. A. M., Junitha, I. K., \& Suaskara, I. B. M. (2017). Pola Pertumbuhan Berdasarkan Berat Dan Tinggi Badan Siswa Pada Sekolah Negeri Dan Swasta Di Kota Denpasar, Bali Growth Pattern Based on Height and Body Weight From Students of Government and Private School At Denpasar, Bali. Jurnal Biologi Udayana, 21(2), 78-87. https:// doi.org/10.24843/JBIOUNUD.2017.vol21.i02.p06

Deki Pem. (2016). Factors Affecting Early Childhood Growth and Development: Golden 1000 Days. Advanced Practices in Nursing, 01(01), 1-4. https://doi.org/10.4172/25730347.1000101

Filial, A. S., \& Rais, M. A. (2021). Analisis Evaluasi Kebijakan Peraturan Desa: Studi Kasus Perdes Bebas Asap Rokok di Desa Bonebone, Kab. Enrekang. Development Policy and Management Review (DPMR), 32-50.

Ginting, I. R., \& Maulana, R. (2020). Dampak Kebiasaan Merokok pada Pengeluaran Rumah Tangga. Jurnal Kebijakan Kesehatan Indonesia : JKKI, 9(2), 77-82.

Hadi Siswanto. (2019). Pendidikan Kesehatan Unsur Utama Dalam Pendidikan Anak Usia Dini. 11(2), 50-57. https://doi.org/10.25078/pw.v2i2.1019

Hadilinatih, B. (2021). Evaluasi Kebijakan Kawasan Bebas Asap Rokok Di Desa Bone-Bone Kecamatan Baraka Kabupaten Endrekang. Jurnal Enersia Publika: Energi, Sosial, Dan Administrasi Publik, 4(2), 248-260.

Herlina, S. (2018). Tumbuh Kembang Bayi Yang Mendapatkan Asi Eksklusif Diwilayah Kerja Puskesmas Simpang Baru Kota Pekanbaru. Jurnal Kebidanan, 7(2), 166. https:// doi.org/10.26714/jk.7.2.2018.166-176

https:// doi.org/10.26714/jk.7.2.2018.166-176

Hidayati, A. (2017). Merangsang Pertumbuhan dan Perkembangan Anak dengan Pembelajaran Tematik Terpadu. Sawwa: Jurnal Studi Gender, 12(1), 151-164. https:// doi.org/10.21580/sa.v12i1.1473

Inten, D. N., \& Permatasari, A. N. (2019). Literasi Kesehatan pada Anak Usia Dini melalui Kegiatan Eating Clean. Jurnal Obsesi : Jurnal Pendidikan Anak Usia Dini, 3(2), 366. https:// doi.org/10.31004/obsesi.v3i2.188

Kemenkes. (2016). Pedoman pelaksanaan stimulasi, deteksi, dan intervensi dini tumbuh kembang anak. Jakarta: Kementrian Kesehatan RI.

Khairatunnisa, K., \& Fachrizal, I. (2019). Hubungan Persepsi Tentang Kawasan Tanpa Rokok (Ktr) Dengan Perilaku Merokok Pegawai Di Dinas Kesehatan Kota Tebing Tinggi Tahun 2018. Jumantik (Jurnal Ilmiah Penelitian Kesehatan), 4(1), 69-81. https://doi.org/10.30829/jumantik.v4i1.4062

Kurnia, R., Guslinda, G., \& Safriyanti, M. (2020). Meningkatkan Perkembangan Membaca Melalui Buku Cerita Rakyat Melayu pada Anak Usia Dini. Jurnal Obsesi: Jurnal Pendidikan Anak Usia Dini, 4(2), 803. https:// doi.org/10.31004/obsesi.v4i2.457

Kusumawardani, N., Tarigan, I., Suparmi, et al, \& Schlotheuber, A. (2018). Socio-economic, demographic and geographic correlates of cigarette smoking among Indonesian adolescents: results from the 2013 Indonesian Basic Health Research (RISKESDAS) survey. Global Health Action, 11(sup1), 54-62. https://doi.org/10.1080/16549716.2018.1467605 
Mayah, I. C. (2021). Hubungan Stress dengan Kebiasaan Merokok pada Komunitas Pendaki Indonesia Korwil Yogyakarta. Jurnal Keperawatan Terpadu (Integrated Nursing Journal), 2(2), 156. https:// doi.org/10.32807/jkt.v2i2.83

Muhammad Amin Rais, A. S. F. (2021). Studi Kasus Perdes Bebas Asap Rokok di Desa Bonebone, Kab. Enrekang. Journal Unhas, 1(1), 32-50.

Najmah, Etrawati, F., Yeni, \& Utama, F. (2015). Studi Intervensi Kawasan Tanpa Rokok pada Tingkat Rumah Tangga Interventional Study of Non-Smoking Area at Household Level. Jurnal Kesehatan Masyarakat Nasional, 9, 375-381. https://doi.org/10.21109/kesmas.v9i4.752

Nurdin, N., \& Anhusadar, L. O. (2020). Evaluasi Pelaksanaan Standar Proses di Satuan Pendidikan Anak Usia Dini. Jurnal Obsesi : Jurnal Pendidikan Anak Usia Dini, 4(2), 982. https:// doi.org/10.31004/obsesi.v4i2.485

Nursalam, 2016, \& Fallis, A. . (2013). Metode Penelitian. Journal of Chemical Information and Modeling, 53(9), 1689-1699. https://doi.org/10.1021/ci400128m

Pasca, I., Nopianti, H., \& Widiyarti, D. (2018). Identifikasi Permasalahan Anak dalam Rangka Pemenuhan Hak Kesehatan dan Kesejahteraan Anak. Jurnal Sosiologi USK (Media Pemikiran \& Aplikasi), 12(2), 161-177.

Pewara, A. (2018). Efektivitas Kebijakan Kawasan Bebas Asap Rokok Di Disa Bone-Bone Kecamatan Baraka Kabupaten Enrekang. Majalah Ilmiah Solusi, 17(2), 1-15.

Prasanti, D., \& Fitrianti, D. R. (2018). Pembentukan Karakter Anak Usia Dini: Keluarga, Sekolah, Dan Komunitas. Pembentukan Anak Usia Dini: Keluarga, Sekolah, Dan Komunitas, 2(1), 15. https://doi.org/10.31004/obsesi.v2i1.2

Primasoni, N. (2019). Manfaat Protein untuk Mendukung Aktifitas Olahraga, Pertumbuhan, dan Perkembangan Anak Usia Dini.

Rahmatia, R., Pajarianto, H., Kadir, A., Ulpi, W., \& Yusuf, M. (2021). Pengembangan Model Bermain Konstruktif dengan Media Balok untuk Meningkatkan Visual-Spasial Anak. Jurnal Obsesi: Jurnal Pendidikan Anak Usia Dini, 6(1), 47-57. https://doi.org/10.31004/obsesi.v6i1.1185

Sari, N. A. M. E., \& Resiyanthi, K. A. (2020). Hubungan Perilaku Merokok Orang Tua Dengan Kejadian Stunting. Jurnal Ilmu Keperawatan Anak, 3(2), 24-30. https://doi.org/10.32584/jika.v3i2.773

Septiani, R., Widyaningsih, S., \& Igohm, M. K. B. (2016). Tingkat Perkembangan Anak Pra Sekolah Usia 3-5 Tahun Yang Mengikuti Dan Tidak Mengikuti Pendidikan Anak Usia Dini (Paud). Jurnal Keperawatan Jiwa, 4(2), 114-125.

Setiawan, F., Novaria, R., Hartono, S., Ilmu, F., Dan, S., \& Politik, I. (2019). Collaborative Governance Dalam Pelaksanaan Perda Kota Surabaya Nomor 2 Tahun 2019 Tentang Kawasan Tanpa Rokok Di Instansi. August 1945.

Tantri, A., Fajat, N. A., \& Utama, F. (2018). Hubungan Persepsi Terhadap Peringatan Bahaya Merokok Pada Kemasan Rokok Dengan Perilaku Merokok Pada Remaja Laki-Laki Di Kota Palembang. Jurnal Ilmu Kesehatan Masyarakat, 9(1), 74-82. https://doi.org/10.26553/jikm.2018.9.1.74-82

Wulandari, H., \& Purwanta, E. (2020). Pencapaian Perkembangan Anak Usia Dini di Taman Kanak-kanak selama Pembelajaran Daring di Masa Pandemi Covid-19. Jurnal Obsesi : Jurnal Pendidikan Anak Usia Dini, 5(1), 452. https:// doi.org/10.31004/obsesi.v5i1.626

Zualichoh, Z., \& Irdawati, S. K. (2020). Hubungan Posisi Anak Dalam Keluarga Dengan Perkembangan Motorik Kasar Balita. Universitas Muhammadiyah Surakarta. 